\title{
Extracellular DNA metabolism in Haloferax volcanii
}

\author{
Scott Chimileski ${ }^{1}$, Kunal Dolas ${ }^{1}$, Adit Naor ${ }^{2}$, Uri Gophna $^{2}$ and R. Thane Papke ${ }^{1 *}$ \\ ${ }^{1}$ Department of Molecular and Cell Biology, University of Connecticut, Storrs, CT, USA \\ ${ }^{2}$ Department of Molecular Microbiology and Biotechnology, George S. Wise Faculty of Life Sciences, Tel Aviv University, Tel Aviv, Israel
}

\section{Edited by:}

Aharon Oren, The Hebrew

University of Jerusalem, Israel

Reviewed by:

Aharon Oren, The Hebrew

University of Jerusalem, Israel

Alexander Beliaev, Pacific Northwest

National Laboratory, USA

${ }^{*}$ Correspondence:

R. Thane Papke, Department of

Molecular and Cell Biology,

University of Connecticut, 91

N. Eagleville Rd., Storrs, CT 06269

USA

e-mail: thane@uconn.edu
Extracellular DNA is found in all environments and is a dynamic component of the microbial ecosystem. Microbial cells produce and interact with extracellular DNA through many endogenous mechanisms. Extracellular DNA is processed and internalized for use as genetic information and as a major source of macronutrients, and plays several key roles within prokaryotic biofilms. Hypersaline sites contain some of the highest extracellular DNA concentrations measured in nature-a potential rich source of carbon, nitrogen, and phosphorus for halophilic microorganisms. We conducted DNA growth studies for the halophilic archaeon Haloferax volcanii DS2 and show that this model Halobacteriales strain is capable of using exogenous double-stranded DNA as a nutrient. Further experiments with varying medium composition, DNA concentration, and DNA types revealed that DNA is utilized primarily as a phosphorus source, that growth on DNA is concentration-dependent, and that DNA isolated from different sources is metabolized selectively, with a bias against highly divergent methylated DNA. Additionally, fluorescence microscopy showed that labeled DNA co-localized with $\mathrm{H}$. volcanii cells. The gene Hvo_1477 was also identified using a comparative genomic approach as a factor likely to be involved in DNA processing at the cell surface, and deletion of Hvo_1477 created a strain deficient in the ability to grow on extracellular DNA. Widespread distribution of Hvo_1477 homologs in archaea suggests metabolism of extracellular DNA may be of broad ecological and physiological relevance in this domain of life.

Keywords: extracellular DNA, Haloferax volcanii, DNA metabolism, Halobacteria, halophiles, archaea, natural competence, archaeal genetics

\section{INTRODUCTION}

Extracellular DNA (eDNA) is present in every natural environment, amounting to a global molecular pool measured in gigatons (Dell'Anno and Danovaro, 2005). Beyond its sheer abundance, eDNA is a major component of the microbial ecosystem as a dynamic reservoir of carbon $(\mathrm{C})$, nitrogen $(\mathrm{N})$, phosphorus (P), nucleotides, and genetic information (Dell'Anno and Danovaro, 2005; Corinaldesi et al., 2007, 2008). eDNA is engaged by prokaryotes through often complex endogenous mechanisms, including degradation by unbound and cellsurface-bound secreted nucleases (Heins et al., 1967; Provvedi et al., 2001; Sakamoto et al., 2001; Schmidt et al., 2007; Godeke et al., 2011a), import and export systems mediating natural DNA uptake (Chen and Dubnau, 2004; Maier et al., 2004; Chen et al., 2005; Averhoff, 2009), and as a major component of biofilms (Steinberger and Holden, 2005; Godeke et al., 2011b; Kiedrowski et al., 2011; Gloag et al., 2013).

Hypersaline environments contain some of the highest measured levels of eDNA (Dell'Anno and Corinaldesi, 2004), possibly due to the preservative effect salt has on nucleic acids and other macromolecules (Tehei et al., 2002). Over three hundred micrograms of eDNA per gram of sediment was measured within the first centimeter beneath the water column of a hypersaline lake (Danovaro et al., 2005). However, the mechanisms through which the halophilic microorganisms living in this environment interact, process, and exploit this potential cellular resource are unknown.

Brines above $15 \%$ salinity and ranging up to saturation are rich in microbial life and are predominated by euryarchaeal species of the order Halobacteriales, a group commonly known as haloarchaea (Benlloch et al., 2001; Papke et al., 2003, 2004; Pasić et al., 2007; Dassarma and Dassarma, 2008; Andrei et al., 2012). A representative species Haloferax volcanii first isolated from Dead Sea sediments in 1975 (Mullakhanbhai and Larsen, 1975) was chosen for this study because it is genetically modifiable, and is a predominant model halobacterial species, and a top archaeal model in general (Bitan-Banin et al., 2003; Allers and Mevarech, 2005; Soppa, 2006; Allers et al., 2010; Blaby et al., 2010; Hartman et al., 2010; Leigh et al., 2011; Atomi et al., 2012). Here we describe an improved understanding of eDNA metabolism in hypersaline environments and the Halobacteria.

\section{MATERIALS AND METHODS STRAINS AND CULTURE MEDIA}

Haloferax volcanii strains (Table 1) were provided by Thorsten Allers of the University of Nottingham, UK and grown in media as previously described (Allers et al., 2004). Hv-YPC contained $144 \mathrm{~g} \mathrm{NaCl}, 21 \mathrm{~g} \mathrm{MgSO}_{4} \times 7 \mathrm{H}_{2} \mathrm{O}, 18 \mathrm{~g} \mathrm{MgCl}_{2} \times 6 \mathrm{H}_{2} \mathrm{O}, 4.2 \mathrm{~g}$ $\mathrm{KCl}, 12 \mathrm{mM}$ Tris- $\mathrm{HCl} \mathrm{pH} 7.5,3.125 \mathrm{ml} 1 \mathrm{M} \mathrm{CaCl}_{2}$ solution, $1.0 \mathrm{ml}$ trace element solution, $5.0 \mathrm{~g}$ yeast extract (Fisher, BP1422), $1.0 \mathrm{~g}$ 
Table 1 | Strains and plasmids.

\begin{tabular}{|c|c|c|}
\hline Strain or plasmid & Relevant properties & References or sources \\
\hline \multicolumn{3}{|l|}{ PLASMIDS } \\
\hline pTA131 & $\begin{array}{l}\text { Integrative vector based on pBluescript II; AmpR with BamHI-Xbal } \\
\text { fragment from pGB70 containing pfdx-pyrE2 }\end{array}$ & Allers et al., 2004 \\
\hline pTA409 & $\begin{array}{l}\text { Shuttle vector based on pBluescript II, with pyrE2 and hdrB markers and } \\
\text { ori-pHV1/4 replication origin }\end{array}$ & Hölzle et al., 2008 \\
\hline pKD131_s1477 & $\begin{array}{l}\text { pTA131 with HindIII-Notl fragment containing Hvo_1477 flanking } \\
\text { regions for pop-in pop-out gene deletion }\end{array}$ & This study \\
\hline pKD409_1477c & $\begin{array}{l}\text { pTA409 with BamHI-EcoRI fragment containing Hvo_1477 and native } \\
\text { upstream promoter }\end{array}$ & This study \\
\hline \multicolumn{3}{|l|}{ STRAINS } \\
\hline \multicolumn{3}{|l|}{ E. coli } \\
\hline $\mathrm{DH} 5 \alpha$ & Used for subcloning and as source of methylated E. coli DNA & Invitrogen, 18263012 \\
\hline $\mathrm{K} 12$ & $\mathrm{dam}^{-} / \mathrm{dcm}^{-}$strain; used for source of unmethylated DNA & New England Biolabs, C2925l \\
\hline \multicolumn{3}{|l|}{ H. volcanii } \\
\hline DS2 & Wild-type & Mullakhanbhai and Larsen, 1975 \\
\hline $\mathrm{H} 26$ & $\Delta p y r E 2$ & Allers et al., 2004 \\
\hline$\Delta H v O_{-} 1477$ & Hvo_ 1477 deletion in $\mathrm{H} 26$ background & This study \\
\hline$\Delta H v{ }_{-} 1477 \mathrm{c}$ & $\Delta$ Hvo_1477 with pKD409_1477c & This study \\
\hline
\end{tabular}

casamino acids (Fisher, BP1424), and $1.0 \mathrm{~g}$ peptone per liter (Fisher, BP1420). Casamino acids medium (Hv-Ca) contained all of the above components except for yeast extract and peptone. Starvation medium (used for starve conditions) contained all components in Hv-YPC other than yeast extract, casamino acids, and peptone. Minimal medium (Hv-min) also shared the same concentration of salts and basic constituents, with the addition of $4.25 \mathrm{ml} 60 \%$ sodium lactate $\left(\mathrm{NaC}_{3} \mathrm{H}_{5} \mathrm{O}_{3}\right), 5.0 \mathrm{ml} 1 \mathrm{M}$ ammonium chloride $\left(\mathrm{NH}_{4} \mathrm{Cl}\right)$ solution, and $2.0 \mathrm{ml} 0.5 \mathrm{M}$ monopotassium phosphate $\left(\mathrm{KH}_{2} \mathrm{PO}_{4}\right)$ buffer $(\mathrm{pH} 7.5)$. Escherichia coli cloning strains and additional bacterial strains used as DNA source and as extracellular nuclease positive control are listed (Table 1) and were grown using standard growth media and conditions.

All media used in growth experiments with variable $\mathrm{C}, \mathrm{N}$ and $\mathrm{P}$ availability were derivates of $\mathrm{Hv}$ - $\mathrm{min}$. Conditions denoted as $\mathrm{CNP}$ contained $\mathrm{C}, \mathrm{N}$ and $\mathrm{P}$ sources $\left(\mathrm{NaC}_{3} \mathrm{H}_{5} \mathrm{O}_{3}, \mathrm{NH}_{4} \mathrm{Cl}\right.$, and $\mathrm{KH}_{2} \mathrm{PO}_{4}$, respectively) at the same final concentration as Hv-min medium above. Additional conditions/media derivatives lacked either sodium lactate, ammonium chloride, and/or potassium phosphate (e.g., NP medium contains $\mathrm{NH}_{4} \mathrm{Cl}$, and $\mathrm{KH}_{2} \mathrm{PO}_{4}$, but no carbon source).

\section{DNA EXTRACTION AND PURIFICATION}

The purity and integrity of supplemented high molecular weight (HMW) DNA was a primary consideration. Chromosomal DNA for supplementation was isolated from source species through standard lysis methods, followed by proteinase $\mathrm{K}$ digestion and ethanol precipitation. DNA was further purified through multiple phenol/chloroform/isoamyl alcohol ( $\mathrm{pH}$ 8.0) extractions until no protein-rich interphase was present, followed by three chloroform/isoamyl alcohol extractions to remove trace phenol and an additional ethanol precipitation. DNA was then dissolved in $10 \mathrm{mM}$ Tris-Cl solution ( $\mathrm{pH} 8$, in DNA-grade water) and passed through a mini polyacrylamide gel filtration spin column according to the manufacturer protocol (Bio-Rad Bio-Spin
P-30, in Tris buffer, 732-6231) to remove small molecules including free nucleotides and oligonucleotides $<20 \mathrm{bp}$ in length. Purified DNA was used fresh for growth experiments to reduce subsequent hydrolysis, and was sterilized with a $0.22 \mu \mathrm{m}$ filter prior to supplementation. RNA was degraded within DNA samples using RNase I (Thermo, FEREN0601) according to manufacturer's protocol, followed by heat inactivation, ethanol precipitation, and resuspension. DNase digested DNA used in growth experiments was digested with DNaseI (Invitrogen, $18068-015)$ for $12 \mathrm{~h}$ at $37^{\circ} \mathrm{C}$. Herring sperm DNA was from Promega (D1811).

DNA concentration and purity was determined using a Nanodrop ND-1000 (OD $260 \mathrm{~nm} / \mathrm{OD} 280 \mathrm{~nm}=1.8$ ) or a Qubit 2.0 fluorometer (Q32866) with dsDNA High Sensitivity kit (Invitrogen, Q32854). HMW DNA was visualized on agarose gels prior to supplementation.

\section{EDNA METABOLISM STUDIES}

For all growth experiments a minimum of three replicate cultures per condition began with an individual $H$. volcanii DS2 colony grown to mid-exponential phase (OD $600 \mathrm{~nm} \sim 0.4$ ) at $42^{\circ} \mathrm{C}$ in liquid $\mathrm{Hv}-\mathrm{YPC}$, washed three times with starvation medium, and diluted in medium specific to the experiment (e.g., starvation medium or Hv-min derivative). When cultures were starved, starvation occurred at $42^{\circ} \mathrm{C}$ for a $\geq 5$ day period prior to supplementation to allow for depletion of internal nutrient stores (particularly phosphorus, see Figure 1B).

Growth on eDNA was tested in several ways: $200 \mu \mathrm{l}$ of culture within 96-well plates (sealed with transparent plastic film to avoid evaporation and salt precipitation), $5 \mathrm{ml}$ of culture within $50 \mathrm{ml}$ plastic culture tubes, $10 \mathrm{ml}$ of culture in glass anaerobic culture tubes (with rubber stoppers and aluminum seals, headspace displaced with $\mathrm{N}_{2}$ and supplemented with $50 \mathrm{mM}$ sodium nitrate), and $20 \mathrm{ml}$ of culture in $125 \mathrm{ml}$ cell culture flasks (baffled and unbaffled). All experiments were conducted at $42^{\circ} \mathrm{C}$. 


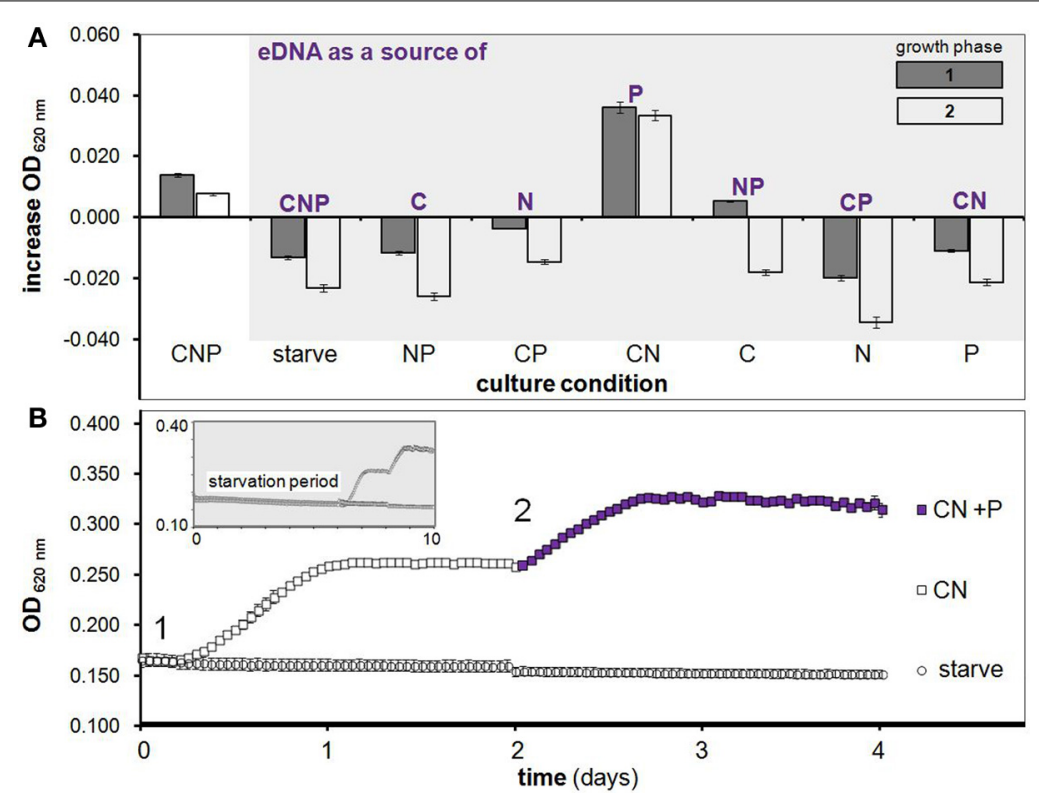

FIGURE $1 \mid \boldsymbol{H}$. volcanii growth on eDNA as a $\mathrm{C}, \mathrm{N}$ and/or $\mathrm{P}$ source.

(A) Increase in OD during two growth phases after starvation (as in growth curve below) with eDNA supplementation in $\mathrm{Hv}$-min medium containing all possible combinations of $\mathrm{C}, \mathrm{N}$ and P. (B) After a 6 day starvation period (shown in smaller gray box) cultures were supplemented with $\mathrm{C}$ and $\mathrm{N}$ (squares) or a negative control starvation solution (circles) at $T=0$ days (point 1 ) with $\mathrm{OD}$ measurements taken every hour. After one round of growth to stationary phase, $\mathrm{KH}_{2} \mathrm{PO}_{4}$ (purple filled squares) was added to $\mathrm{CN}$ cultures as a $\mathrm{P}$ source at point 2 and induced a second growth phase. Error bars are SD of replicate cultures.
Cultures were shaken at $180 \mathrm{rpm}$, other than anaerobic tubes (not shaken).

For experiments with either eDNA and/or C, N, and $\mathrm{P}$ sources added after a starvation period (no $\mathrm{C}, \mathrm{N}$ or $\mathrm{P}$ ), supplementation occurred through a $10 \% \mathrm{v} / \mathrm{v}$ addition of purified DNA solution, and/or $10 \times$ sodium lactate, ammonium chloride or monopotassium phosphate solution (in DNA solvent, $10 \mathrm{mM}$ Tris-Cl, $\mathrm{pH}$ 8.0 ), or negative control solution ( $10 \mathrm{mM}$ Tris- $\mathrm{Cl}, \mathrm{pH} 8.0$ ). Optical density measurements of replicate cultures were taken on a shaking and incubating microplate reader (ThermoFisher Multiskan FC, measurement filter $620 \mathrm{~nm}$ ) or a Biorad SmartSpec Plus $(600 \mathrm{~nm})$ over a 5-10 day period (depending on length of starvation, or induction of several growth phases as in Figure 1). All OD values from culture tube or flask experiments were measured using the Biorad SmartSpec Plus and are greater than identical samples read in 96-well microplates on Multiskan FC; this is caused by the difference in measured wavelength (600 and $620 \mathrm{~nm})$ and a volume added to each microplate well $(200 \mu \mathrm{l})$ less than the full path length $(1 \mathrm{~cm})$. Therefore, there are non-random differences in OD values between experiments measured by OD at 600 and $620 \mathrm{~nm}$.

Viable cell count experiments were conducted within 96-well microplates. Triplicate $H$. volcanii DS2 cultures were starved of $\mathrm{KH}_{2} \mathrm{PO}_{4}$ for 5 days in Hv-min $\mathrm{CN}$ medium after which samples were removed at indicated time points. The $T=0$ sample was taken after the addition of DNA solvent or unmethylated E. coli DNA to a final concentration of $500 \mu \mathrm{g} / \mathrm{ml}$, and optical density was monitored simultaneously. After 4 days the stationary phase sample was taken and cell titers were quantified through a serial dilution of each culture and plating for colony forming units (CFUs) on Hv-YPC medium.
Where significant difference is noted between conditions for growth experiment results, significance of difference between data series was determined by One-Way ANOVA test of the mean for each replicate set ( $n \geq 3$ biological replicates). A significant difference between means was defined as a $P \leq 0.05$, while no significant difference between two means was defined as a $P \geq 0.05$. Where increase in OD is shown, average increase in OD was calculated by subtracting the initial OD value at time zero, or OD of control culture (e.g., value for $\mathrm{CN}$ medium alone from value for $\mathrm{CN}+\mathrm{eDNA}$ ), from the final value achieved after incubation for each replicate.

\section{ASSESSMENT OF EXTRACELLULAR DNase ACTIVITY}

Conditioned media (CM) was harvested from H. volcanii DS2 and Staphylococcus aureus (as a positive control) by centrifuging exponential phase (OD $600 \mathrm{~nm} \sim 0.6)$ cells grown in rich medium and passing the supernatant through a $0.22 \mu \mathrm{m}$ filter. Medium had been previously inoculated with a single colony. CM harvested from the two species was supplemented with $30 \mu \mathrm{g}$ of unmethylated pTA131 plasmid DNA (final concentration $150 \mathrm{ng} / \mu \mathrm{l}$ ), and incubated for $12 \mathrm{~h}$ at $37^{\circ} \mathrm{C}$. During this time, secreted nuclease in the $\mathrm{CM}$ is exposed to and may degrade high molecular weight DNA fragments, resulting in smearing of lower molecular weight DNA detectable on an agarose gel stained with ethidium bromide. The DNase I positive control digestion was performed according to manufacturer protocol (Invitrogen, 18068-015).

\section{FLUORESCENCE MICROSCOPY}

One microgram of unmethylated E. coli DNA as prepared for growth studies was first digested for $10 \mathrm{~min}$ with DNase I (Invitrogen, 18068-015) to increase reaction efficiency and probe 
fragmentation and labeled with the Ulysis Alexa Fluor ${ }^{\circledR} 488$ Nucleic Acids Labeling Kit (Molecular Probes, U-21650). The labeling reaction occurs during an $80^{\circ} \mathrm{C}$ incubation step, creating an irreversible complex between the Alexa Fluor ${ }^{\circledR}$ fluorophore and guanine and adenine bases. Labeled DNA was purified from un-reacted probe using mini-gel filtration spin columns (Bio-Rad Bio-Spin P-30, in Tris buffer, 732-6231) as recommended.

$H$. volcanii DS2 cells were grown to mid-log phase (OD 0.4) in Hv-YPC medium, pelleted, washed three-times and resuspended in a basal salts medium (Hv-starve). Cells were incubated with freshly labeled and purified DNA at a final concentration of $10 \mathrm{ng} / \mu \mathrm{l}$ for $1 \mathrm{~h}$ at $42^{\circ} \mathrm{C}$, after which they were pelleted once again and suspended in Hv-starve medium to remove excess probe. Preparations of live cells were visualized immediately using a Nikon ECLIPSE TE-300 inverted fluorescence microscope. Photographs of labeled cells viewed at $600 \times$ total magnification were collected under white light and with excitation at $488 \mathrm{~nm}$ (pseudocolored green). Cells did not autofluoresce at the tested excitation wavelength as verified by no detectable signal in identically prepared unlabeled cells.

\section{IDENTIFICATION OF PUTATIVE DNA METABOLISM GENE Hvo_1477 AND RELATED GENES}

The Hvo_1477 protein (YP_003535526) was identified as a putative membrane-bound nuclease involved in DNA metabolism through a BLASTP search (Altschul et al., 1990) of the H. volcanii genome (Hartman et al., 2010) using known bacterial proteins (Table 2) as queries. Hvo_1477 was targeted as a homolog of bacterial nuclease YokF (YP_007534137). Clusters of Orthologous Groups or COGs (Tatusov, 1997), protein domains, and protein superfamilies (Gough and Chothia, 2002; Sigrist et al., 2013) were identified using the MicrobesOnLine portal (Dehal et al., 2010).

The phylogenetic tree of archaeal YokF/Hvo_1477 homologs was created using Seaview (Gouy et al., 2010). All homologs shown have an $E$-value of $1 \mathrm{e}-10$ or lower in a pairwise BLASTP with YokF and were aligned with Clustal Omega (Sievers et al., 2011). The tree was constructed using PhyML (Guindon and Gascuel, 2003).

\section{GENE DELETION AND COMPLEMENTATION}

Deletion of Hvo_1477 was carried out using the pop-in pop-out method as previously described (Bitan-Banin et al., 2003; Allers et al., 2004). Briefly, the upstream flanking region of Hvo_1477 was amplified and restriction sites were incorporated into PCR products within primers (Table 3). The PCR products were purified using a Qiagen PCR purification kit (Qiagen, 28106) and digested with EcoRI (enzymes were purchased from New England Biolabs). The flanking region products were then purified using a Qiagen gel purification kit (Qiagen, 28706) and ligated with T4 ligase (Promega, M1804). The final product was verified using the forward primer of the upstream flanking regions and the reverse primer of the downstream flanking region (Table 3). Plasmid pTA131 (Table 1) and ligated flanking regions were digested with HindIII and NotI and the digested products were gel purified and ligated. The ligated plasmid (pTA131_ 1477del) was transformed into competent E. coli cells from New England Biolabs (Table 1), grown on LB-ampicillin plates and extracted from isolated ampicillin resistant colonies. Competent cells of $H$. volcanii strain H26 were made and transformed with the extracted plasmid via the standard polyethylene glycol method (Charlebois et al., 1987; Dyall-Smith, 2009) and plated on Hv-Ca medium for pop-in. Pop-in colonies were selected through colony PCR and plated on Hv-Ca with 5-FOA (Zymo Research, F9003) to counter-select for pop-outs. Final deletion mutants were identified through a colony PCR screen of 5-FOA resistant colonies.

For complementation plasmid construction, the native promoter for Hvo_1477 was predicted with the Neural Network Promoter Prediction site (http://www.fruitfly.org/seq_ tools/promoter.html) and primers were constructed (Table 3) to include this region (beginning $125 \mathrm{bp}$ from the start codon of Hvo_1477). The product containing Hvo_1477 and promoter was ligated into pTA409 after digestion and gel purification of insert and plasmid with BamHI and EcoRI, creating the plasmid pKD409_1477c (Table 1). The product was transformed into competent E. coli cells and colonies were selected and confirmed using PCR. Amplified product was purified, transformed into $H$. volcanii $\triangle H v o \_1477$ cells (Table 1) and then plated for selection on $\mathrm{Hv}-\mathrm{Ca}$ plates. Colonies that had regained uracil prototrophy and grew on $\mathrm{Hv}-\mathrm{Ca}$ were grown in liquid medium and the final complemented strain ( $\triangle H v_{v o \_} 1477 \mathrm{c}$, Table 1) was confirmed using colony PCR.

\section{RESULTS}

eDNA METABOLISM AND PRIMARY ROLE AS A PHOSPHORUS SOURCE

An ability to utilize eDNA to drive metabolic growth in $H$. volcanii was observed using several experimental platforms and methods. We first used 96-well microplates as a routine method for monitoring growth through optical density of replicate cultures, and discovered an increase in OD of $H$. volcanii cultures after supplementation with RNase treated, freshly precipitated and highly purified HMW double-stranded DNA (as in Figure 1). Initial experiments were followed by additional microplate-based studies whereby all possible combinations of typical $\mathrm{C}, \mathrm{N}$ and $\mathrm{P}$ sources were supplemented after a starvation period (aimed at depletion of intracellular stores).

This next phase of starvation experiments lead to the principle findings that (i) $H$. volcanii stores phosphorus intracellularly, and (ii) eDNA is utilized primarily as a source of phosphorus. Internal $\mathrm{P}$ storage is demonstrated by the observation that cells starved of $\mathrm{C}, \mathrm{N}$ and $\mathrm{P}$ for 6 days and then supplemented with $\mathrm{C}$ and $\mathrm{N}$ but not $\mathrm{P}$ were able to reproduce through approximately one growth phase (Figure 1B). A second growth phase was then induced in these same replicate cultures by the addition of $\mathrm{KH}_{2} \mathrm{PO}_{4}$ alone, further indicating that cessation of growth was indeed due to P limitation (Figure 1B, purple squares). Likewise, eDNA's role as a $\mathrm{P}$ source is demonstrated by the observation that eDNA supplementation in starved cultures led to a significant growth advantage only when cultures were provided with $\mathrm{C}$ and $\mathrm{N}$ (CN medium, Figure 1A)-further verified with a second addition of eDNA after CN culture cells had reached the stationary phasewhich caused a second phase of exponential growth, again only in $\mathrm{CN}$ medium (Figure 1A, white bars). DNaseI digested DNA was also tested and led to growth in $\mathrm{CN}$ medium equal to that of undigested DNA (data not shown), indicating $H$. volcanii can 
Table 2 | Hvo_1477 protein homologs with known functions.

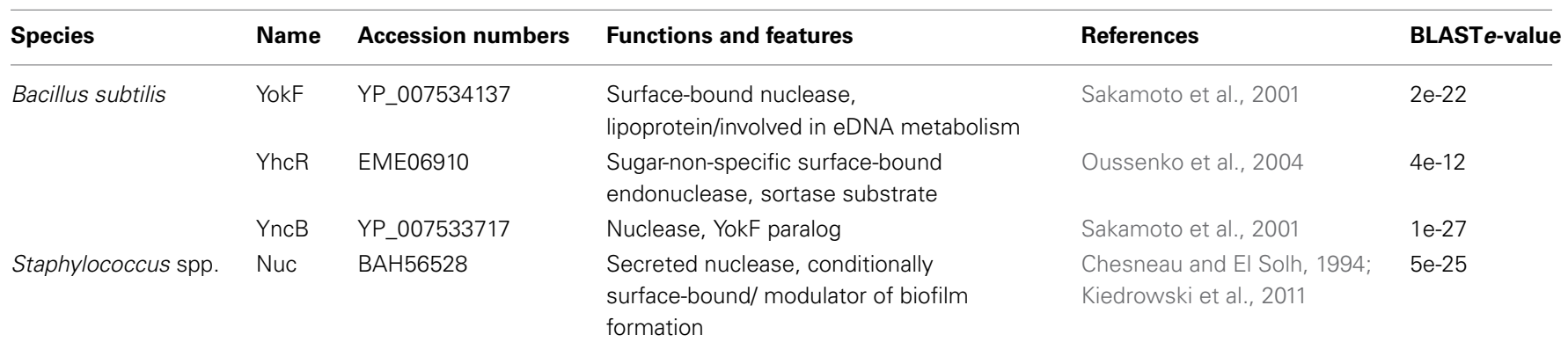

Table 3 | Oligonucleotide primers used.

\begin{tabular}{lll}
\hline Primer & Sequences $\left(\mathbf{5}^{\prime} \mathbf{- 3}^{\prime} \mathbf{~}^{\mathbf{a}}\right.$ & Properties \\
\hline Hvo_1477FR1_F & TTTAAGCTTCGTGCGCCCGATTTCCTTCT & Hvo_1477 deletion, upstream region external, HindIII site \\
Hvo_1477FR1_R & TTTGAATTCTCGATTCACCGTTAGTCAGGG & Hvo_1477 deletion, upstream region internal, EcoRI site \\
Hvo_1477FR2_F & AAAGAATTCCGACGAATTCTCGCGTACA & Hvo_1477 deletion, upstream downstream region internal, EcoRI site \\
Hvo_1477FR2_R & TTTGCGGCCGCCGAGATGCGCGGCGAGGT & Hvo_1477 deletion, downstream region external, Notl site \\
Hvo_1477P_F & AAAGGATCCGTTCCATTAAAAGGTTTCTGGT & Forward complementation, with native promoter, BamHI site \\
Hvo_1477_R & AAAGAATTCCAGTGTCTCCCCGAACAGCGG & Complementation, reverse, EcoRI site
\end{tabular}

${ }^{a}$ Restriction endonuclease sites are underlined.

utilize nucleotides and small olgionucleotide products in addition to HMW DNA. While microplate experiments are useful for high-throughput assays encompassing many conditions, concerns regarding growth limitation due to small culture volume and oxygen availability led us to validate observed trends using several independent culturing methods and conditions.

Further OD-based studies included a dose-dependence experiment, in addition to culturing in larger volumes within baffled and unbaffled flasks (Figure 2), and in culture tubes during both aerobic (Figures 3A,B) and anaerobic conditions (Figure 3C). As expected, a linear relationship between increasing eDNA concentration and OD $600 \mathrm{~nm}$ was measured during growth in $\mathrm{CN}$ medium: with absorbance readings reaching $129 \%$ above control values at $250 \mu \mathrm{g} / \mathrm{ml}$ (Figure 3B). A scaled-up experiment with $20 \mathrm{ml}$ of culture grown in culture flasks $(100 \times$ greater volume than microplate wells) was conducted with OD readings taken after eDNA or DNA solvent was supplemented in NP, $\mathrm{CP}$ or $\mathrm{CN}$ medium inoculated with starved $H$. volcanii cells. As in microplate-based experiments, growth in each medium type without eDNA is indicative of a capacity for internal storage of the missing macronutrient. Relatively weak but significant growth ( $P$-value of 0.002 when compared to starvation cultures) without eDNA was only measured in $\mathrm{CN}$ medium, affirming internal $\mathrm{P}$ storage, and suggesting insufficient internal $\mathrm{C}$ or $\mathrm{N}$ stores capable of driving cellular division (Figure 2). Also consistent with microplate experiments, eDNA supplementation led to a large increase in OD only in $\mathrm{CN}$ medium, and a small but significant increase in CP medium, confirming the use of eDNA as a P source and suggesting a role as a weak nitrogen source (Figure 2). Cell cultures grown in anaerobic tubes during nitrate respiration were also able to utilize eDNA as a $\mathrm{P}$ source (Figure 3C).

Viable cell counts also verified growth on eDNA as a $\mathrm{P}$ source. Averaged CFUs at stationary phase for a culture starved of $\mathrm{P}$ (through growth in $\mathrm{CN}$ media, as in Figure 1B) within a microplate were over seventy times greater with eDNA supplementation as compared to control cultures (DNA solvent alone) (Table 4). The optical density-based growth curve for this culture indicated approximately one doubling during this same period (Table 4), typical of most eDNA supplementation experiments described here. This indicates that while OD measurements are useful for revealing overall trends, viable cell numbers are underestimated, likely due to difference in light scattering properties such as cell shape, size, and intracellular composition.

\section{SELECTIVE METABOLISM OF AVAILABLE eDNAs}

Our first observation of growth on eDNA occurred when supplementing $H$. volcanii with its own genomic DNA (i.e., conspecific DNA). However, we soon noticed an inability to metabolize certain DNA types when we attempted to grow $H$. volcanii on eDNA extracted from other DNA sources. This began with an inability to utilize herring sperm DNA and E. coli DNA (no growth advantage in $\mathrm{CN}$ media, Figure 4).

We then tested additional DNA types in order to identify any features or properties of available eDNA that could be discriminated by $H$. volcanii cells and any associated molecular components involved in DNA metabolism. After a bioinformatic search for DNA uptake signals like those found throughout the genomes of many competent Gram negative bacteria (Redfield et al., 2006) produced no putative short hyper-represented motifs, 


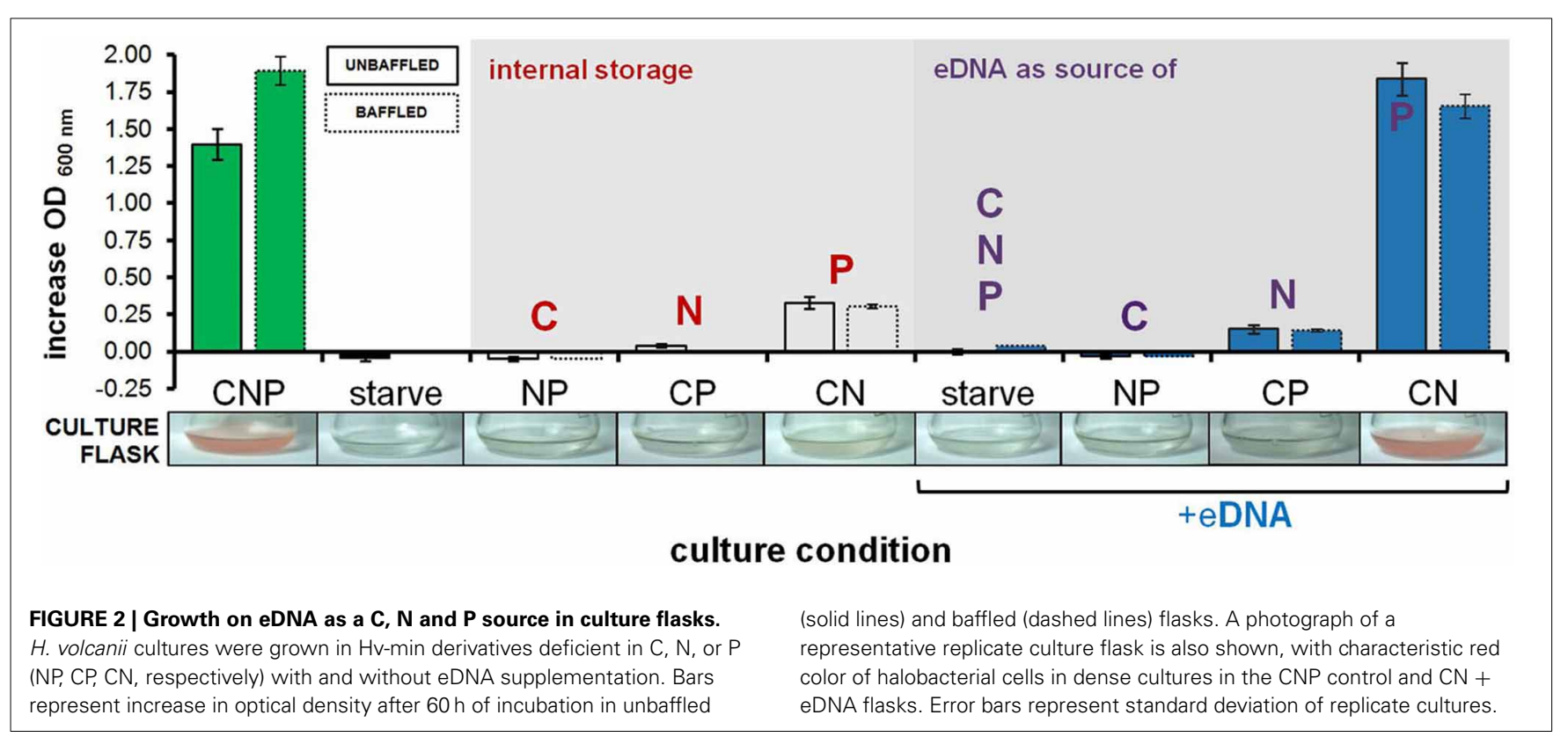

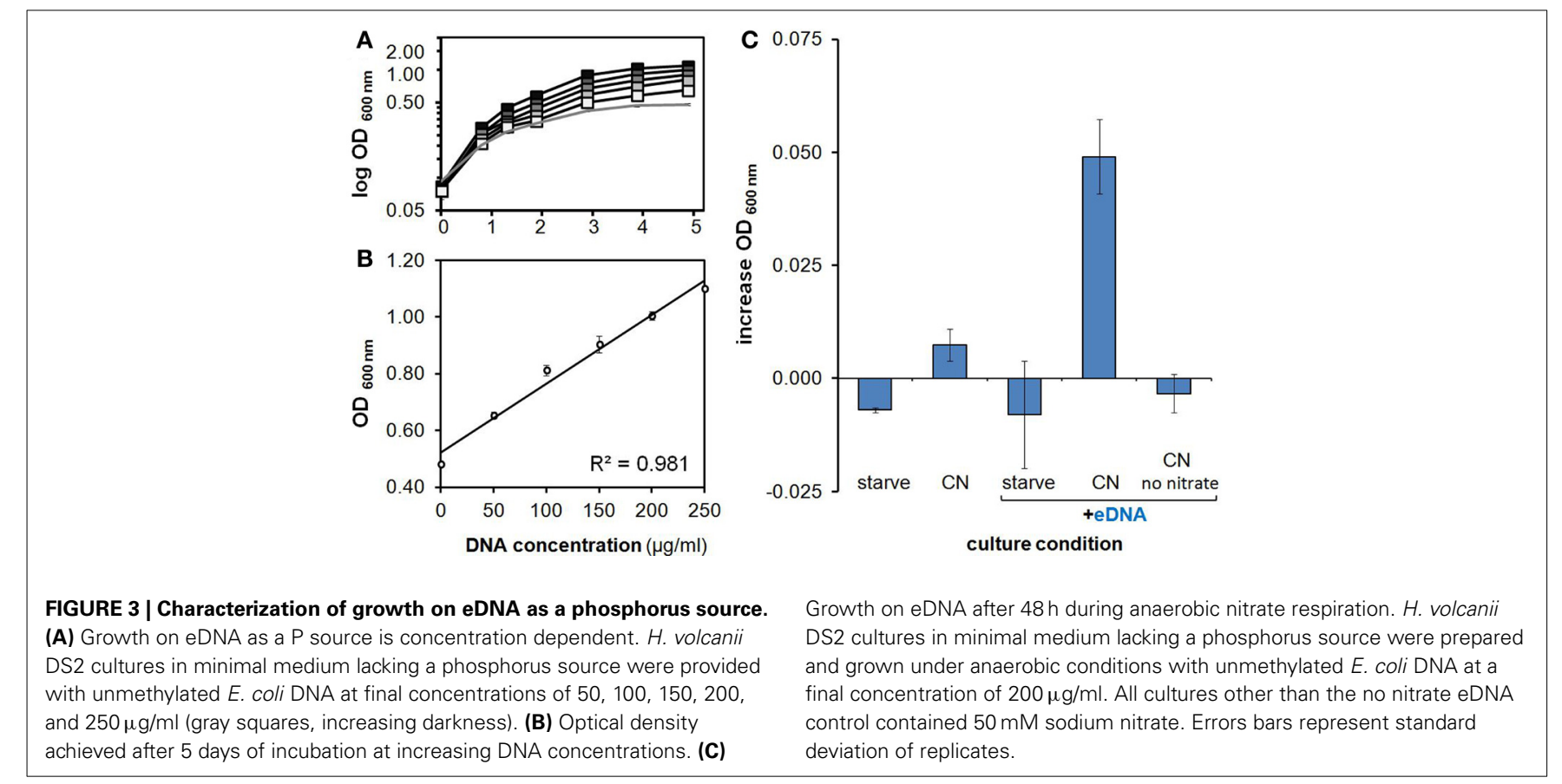

Table 4 | Viable cell count of phosphorous-starved DNA supplemented $\boldsymbol{H}$. volcanii DS2 cultures.

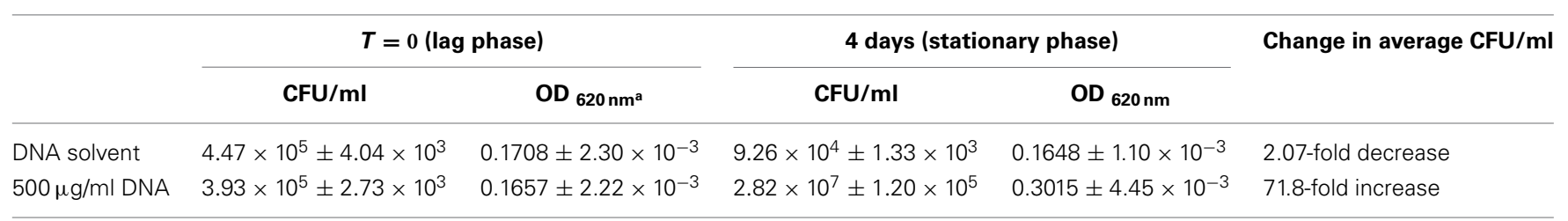

${ }^{a}$ Corresponding optical density at time of sampling. Error shown is $S D$ of counts from triplicate cutures. 
we supplemented $H$. volcanii cultures with eDNA extracted from Micrococcus luteus, a divergent bacterial species with a high G-C content similar to that of the Haloferax volcanii genome (Hartman et al., 2010), and again observed no growth (data not shown). This decreased the likelihood that selectivity was primarily due to an uptake signal sequence feature or G-C content and we moved on to chemical modification of eDNA by methylation.

DNA extracted from an E. coli K12 strain with dam and dcm DNA methyltransferases deleted (Table 1) was tested, and we observed that along with conspecific DNA, unmethylated E. coli DNA led to a significant increase in OD at stationary phase (Figure 4). An E. coli strain with a single DNA methylation gene deleted (dam) was also tested and showed significant growth between that of fully methylated (DH5 $\alpha$, no growth) and unmethylated DNA (data not shown). Unmethylated E. coli DNA fragments were also labeled with a fluorescent probe and incubated with $H$. volcanii in liquid culture to test for association of cells with eDNA. A majority of cells as visualized under white light (first panel) co-localized with strong signal from labeled eDNA

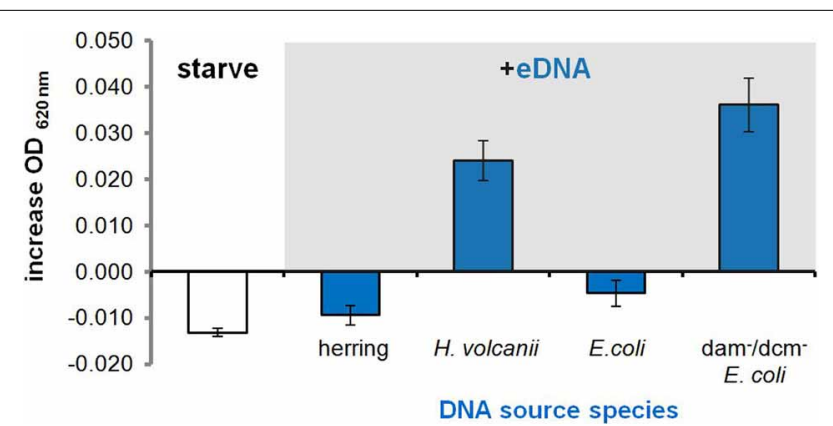

FIGURE 4 | Selective metabolism of available eDNAs. Average increase in OD of P-starved $\mathrm{H}$. volcanii cultures in $\mathrm{CN}$ medium 16 hours after supplementation with $250 \mu \mathrm{g} / \mathrm{ml}$ eDNA isolated from different source species. Error bars are standard deviation of replicates.
(Figure 5, third panel), while some visible cells in the focal plane appear not to co-localize with eDNA (Figure 5, third panel, white arrows).

\section{SCREENS FOR HYDROLASE ACTIVITY WITHIN CONDITIONED MEDIUM INDICATE ABSENCE OF UNBOUND SECRETED NUCLEASE}

DNase activity from CM was assayed to evaluate the presence of hydrolytic enzyme secreted into the environment during growth. CM from the nuclease secreting bacterial species $S$. aureus (Figure 6, lane 5) produced the expected smear of DNA fragments ranging from $\sim 2000$ to $200 \mathrm{bp}$, with none of the original bands remaining. DNA within $H$. volcanii $\mathrm{CM}$ remained intact (Figure 6, lane 7), as in lane 2 in which DNA was added to non-conditioned medium, indicating an absence of evidence for eDNA degradation in $H$. volcanii CM. Previous studies have

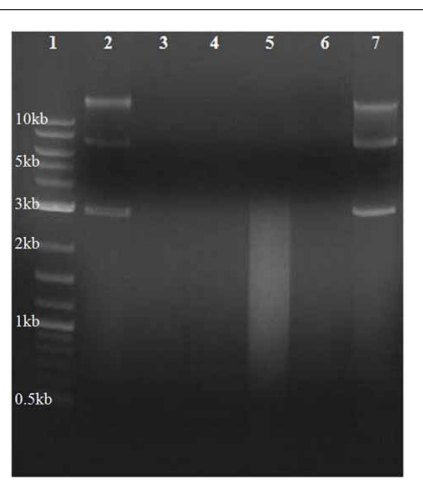

FIGURE 6 | Assay for secreted unbound nuclease activity in $\boldsymbol{H}$. volcanii. Conditioned media was harvested from $H$. volcanii and $S$. aureus cultures, supplemented with plasmid DNA, and incubated at $37^{\circ} \mathrm{C}$. Gel electrophoresis of DNA samples recovered after $12 \mathrm{~h}$ of incubation with $\mathrm{CM}$ is shown. Lane numbers are (1) 2-log DNA ladder (NEB N3200L), (2) DNA incubated with unconditioned LB medium, (3) DNA incubated with DNase I, (4) $S$. aureus $C M$, (5) $S$. aureus $C M$ incubated with DNA, (6) H. volcanii CM, and (7) $H$. volcanii $\mathrm{CM}$ incubated with DNA.

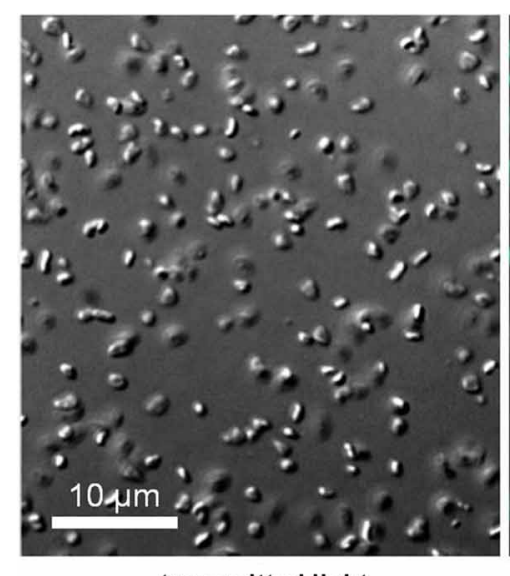

transmitted light

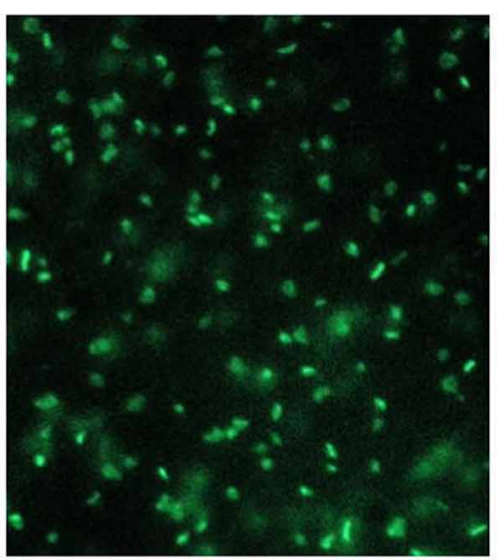

Alexa Fluor 488 labeled eDNA

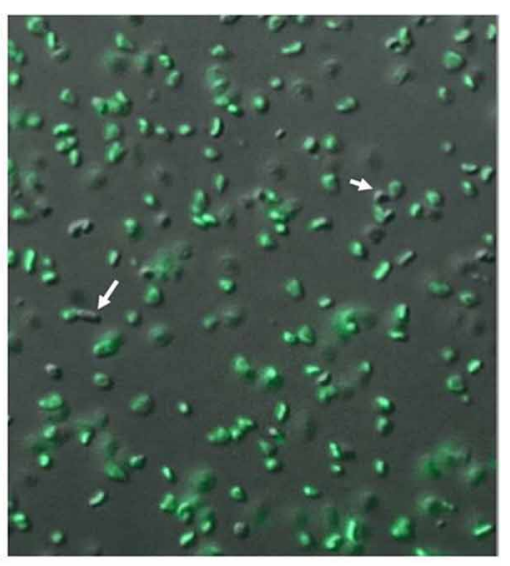

overlay

FIGURE 5 | Co-localization of labeled eDNA and Haloferax volcanii cells. Unmethylated E. coli DNA was labeled with Alexa Fluor 488, incubated with starved cells, and visualized at $600 \times$ using an epifluorescence microscope. Auto-fluorescence was not detected at excitation wavelength. 


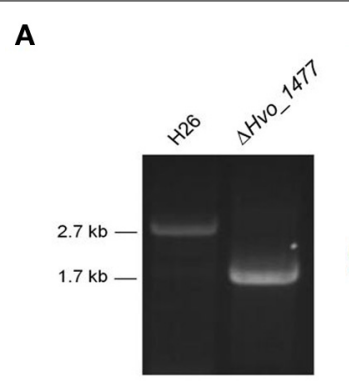

C
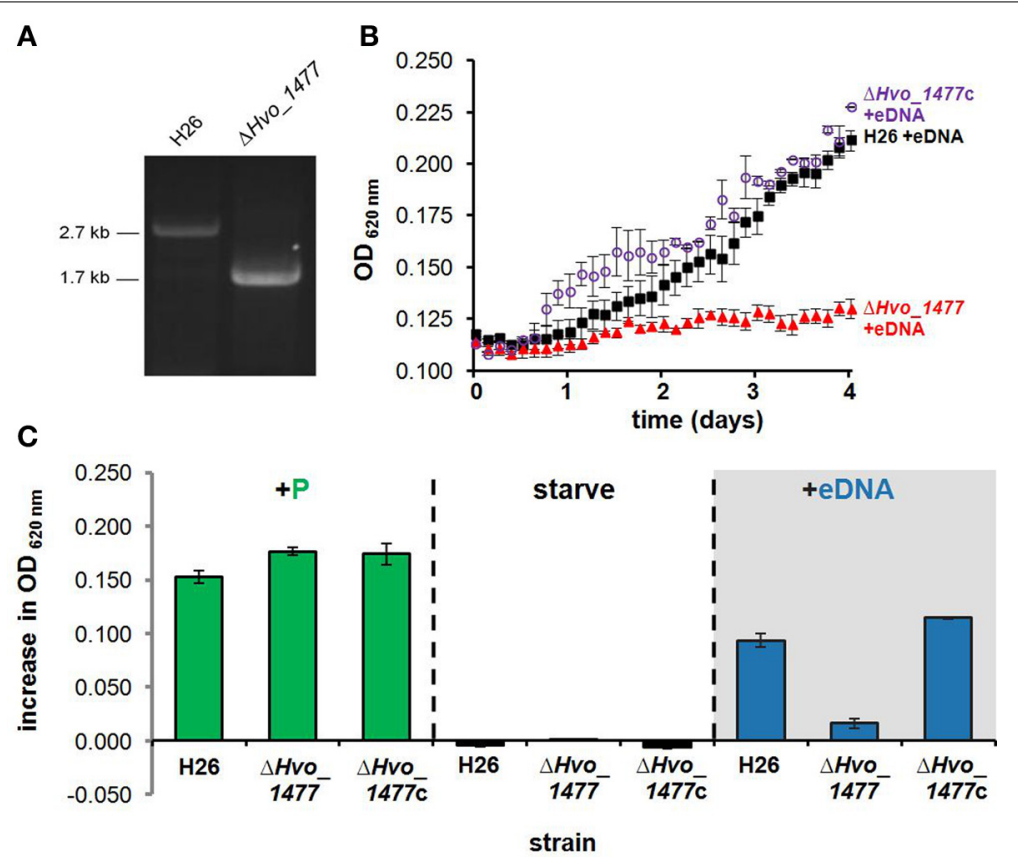

black filled squares), $\Delta H v$ o_ $_{1477}$ (red filled triangles) and $\Delta H v v_{-} 1477$ with pKD409_1477c complementation plasmid ( $\Delta$ Hvo_ $1477 \mathrm{c}$, purple circles). OD was measured every $3 \mathrm{~h}$ within a shaking and incubated 96-well plate reader. (C) Increase in optical density $96 \mathrm{~h}$ after supplementation with $\mathrm{KH}_{2} \mathrm{PO}_{4}$, DNA solvent (continued starvation), or eDNA. Error bars represent standard deviation of triplicate cultures.
FIGURE 7 | Hvo_ 1477 is required for growth on DNA. (A) Deletion of chromosomal gene Hvo_1477 in $\mathrm{H}$. volcanii strain H26. PCR amplification of $\mathrm{H} 26$ and $\triangle H v$ o_$_{-} 1477$ template DNA using the forward primer for the upstream Hvo_1477 flanking region, and the reverse primer of the downstream flanking region (Hvo_1477FR1_F and Hvo_1477FR2_R,

Table 3). (B) Growth with eDNA in CN media for $\mathrm{H}_{26} 6$ (parental strain,

Table 5 | Annotated features/domains of Hvo_1477.

\begin{tabular}{llll}
\hline ID & Database*/domain ID & Start/end & Description \\
\hline PROKAR_LIPOPROTEIN & PS51257 & $1 / 20$ & Lipobox motif \\
TNASE_3 & PS50830 & $67 / 92$ & Thermostable nuclease domain \\
Micrococcal nuclease & COG1525 & $23 / 215$ & Micrococcal nuclease domain \\
Staphylococal nuclease & SSF50199 & $55 / 203$ & Staphylococcal nuclease superfamily \\
Helix-turn-helix & HTH & $171 / 192$ & DNA binding motif \\
Thermonuclease active site & PS01123 & $67 / 92$ & Active site of thermonuclease \\
Lamin A/C globular tail & SSF74853 & $236 / 326$ & No putative function \\
\hline
\end{tabular}

*Database abbreviations: PS, PROSITE Database (Sigrist et al., 2013); COG, Cluster of Orthologous Groups (Tatusov, 1997); SS, SCOP Superfamily Database (Gough and Chothia, 2002).

also reported a lack of secreted nucleases in haloarchaeal species (Ventosa et al., 2005).

\section{Hvo_1477 IS IMPORTANT FOR DNA METABOLISM IN $\boldsymbol{H}$. volcanii}

Deletion of Hvo_1477 diminished growth on DNA (Figure 7). This phenotype was confirmed by complementation with plasmid pKD409_1477 (Table 1) containing Hvo_1477 and its native promoter, and resulted in the restoration of growth on DNA to levels slightly greater $(P=0.049)$ than that of the parental strain (H26, Figure 7), possibly due to multiple copies of the plasmid. No additional phenotype for the $\Delta H v v_{-} 1477$ strain has been observed at the time of publication; growth rates in minimal medium (Hv-min) with sodium lactate as a carbon source are equal to that of $\mathrm{H} 26$ (Figure 7, $+\mathrm{P}$ ).
Hvo_1477 is a 327 aa protein that has a predicted size of $34.1 \mathrm{kDa}$, several annotated sequence features (Table 5), and is homologous to known bacterial extracellular nuclease proteins YokF, YhcR, and YncB of Bacillus subtilis, and Nuc of staphylococcal species (Chesneau and El Solh, 1994) (Table 2). While the Hvo_1477 gene and associated haloarchaeal homologs are annotated as competence-like protein-encoding genes or $\operatorname{com} A$, there is no homology between the Hvo_1477 protein sequence and bacterial competence protein orthologs ComA/ComEC, which contain multiple membrane-spanning regions and are known to form an aqueous DNA pore during natural DNA uptake (Facius and Meyer, 1993; Draskovic and Dubnau, 2005) (Figure 8). The basis for this annotation may be that some halobacterial homologs of Hvo_1477 (including Halobacterium sp. NRC-1, as 


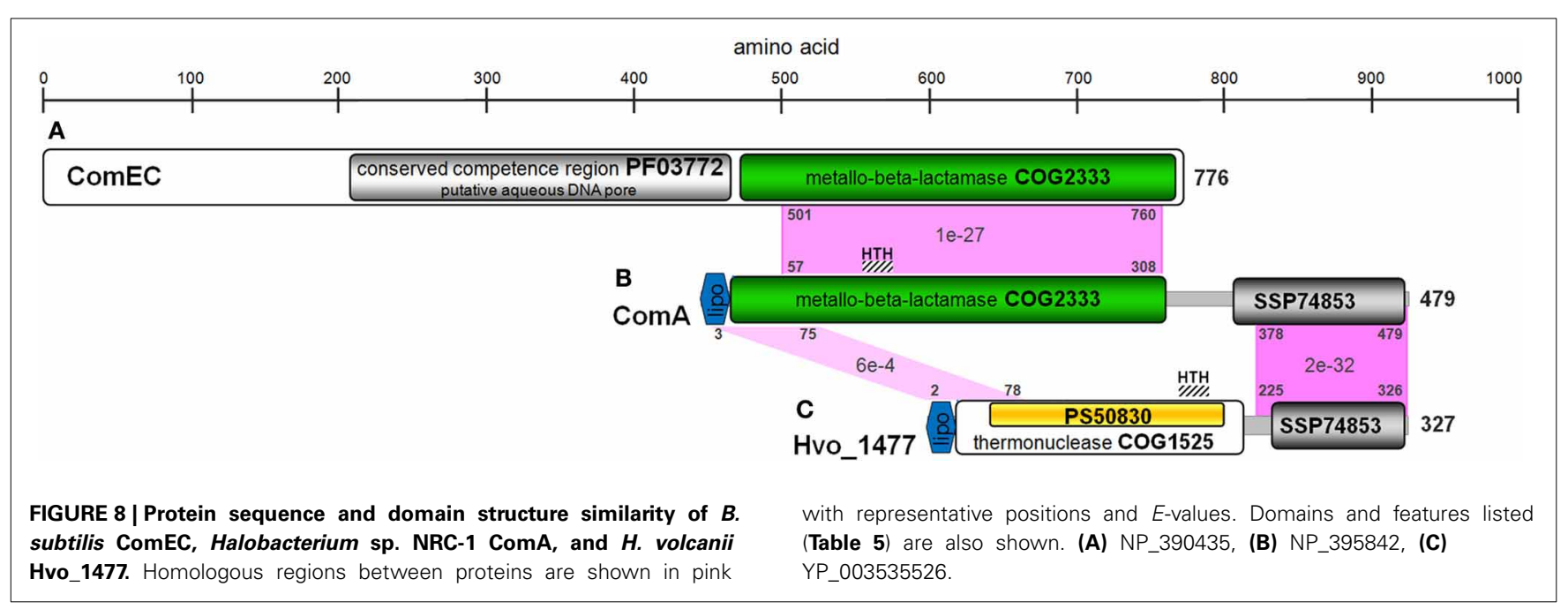

shown in Figure 8) are larger proteins containing an additional metallo-beta-lactamase domain (COG 2333) that does share a region of similarity with bacterial ComA/ComEC. These larger haloarchaeal bacterial nuclease homologs clustered together in the phylogenetic tree of Hvo_1477 homologs (Figure 9, group 2), and some species such as Haloarcula marismortuti have both the smaller thermonuclease containing (see Figure 9, group 1), and larger metallo-beta-lactamase containing version. However, homology of group 2 proteins (Figure 9) with ComEC/ComA appears to be based on only a single shared domain (COG 2333): all haloarchaeal homologs are missing the important putative DNA pore domain or "conserved competence region" (Figure 8).

\section{DISCUSSION}

The discovery of an ability to metabolize HMW eDNA in the Halobacteria is a central finding of this work. While bacterial species are known to use eDNA as a nutrient source (Finkel and Kolter, 2001; Sakamoto et al., 2001; Palchevskiy and Finkel, 2006; Lennon, 2007; Pinchuk et al., 2008; Mulcahy et al., 2010), here we report this capacity in an archaeon. Most bacterial species known to use DNA as a nutrient metabolize DNA as a source of $\mathrm{C}, \mathrm{N}$ and/or P; here we show that $H$. volcanii uses eDNA almost exclusively as a source of phosphorus (Figures 1, 2).

Our experimental demonstration of DNA metabolism as a $\mathrm{P}$ source in $H$. volcanii adds to previous reports showing that (i) eDNA concentrations are exceptionally high in hypersaline sample sites and (ii) organisms living in hypersaline environments are often limited by phosphorus (Oren and Shilo, 1982; Oren, 1983; Ludwig et al., 2006). We therefore propose that nutritional DNA uptake may be a primary mechanism through which haloarchaeal species obtain phosphorus and that DNA is likely a major currency of $\mathrm{P}$ exchange and storage in hypersaline environments. DNA is indeed a P-rich molecule ( $10 \%$ by weight), and has been shown to account for over $40 \%$ of $\mathrm{P}$ cycling in some environments (Dell'Anno and Danovaro, 2005; Corinaldesi et al., 2007, 2008). Interestingly, because $H$. volcanii is highly polyploid, intracellular DNA stores may also be important for biogeochemical systems in the environment (Soppa, 2013). Furthermore, the distribution of Hvo_1477 homologs throughout the Euryarchaeota (Figure 9) suggests DNA metabolism could be an important physiological ability relevant in many species and ecosystems.

We also discovered a bias in metabolism toward conspecific and unmethylated eDNAs, whereby highly divergent eDNA is only utilized when unmethylated (Figure 4). Because H. volcanii methylates its own DNA (Hartman et al., 2010), we suggest available eDNAs are processed through recognition of methylation patterns. This is the first report demonstrating the importance of methylation for eDNA discrimination and the extent of this characteristic among other prokaryotes is unknown. However, the presence of such a system for discrimination of eDNA offers a possible explanation to the finding that eDNA accumulates and remains preserved in environments despite high overall levels of DNase activity (Corinaldesi et al., 2008). High concentrations of eDNA found in a particular environment may reflect the inability of all organisms living there to utilize the available DNA because they cannot process and/or import it. For instance, there are many bacterial and eukaryal cells that live in hypersaline environments, and their DNA would not be methylated in a manner that $H$. volcanii can recognize and utilize.

Hvo_1477 is the first eDNA processing/uptake related gene identified in an archaeon-a starting point toward understanding an archaeal eDNA degradation mechanism and associated phenotypes. Hvo_1477 is not a ComA/ComEC homolog, but is instead a putative lipoprotein with a thermonuclease domain (Tables 2, 5, Figures 8, 9). Lipoproteins are secreted and attached to the cell surface in both bacterial and archaeal species (Szabo and Pohlschroder, 2012) and surface-bound nucleases in bacteria such as the YokF-related B. subtilis Hvo_1477 homologs listed in Table 2 (Sakamoto et al., 2001; Oussenko et al., 2004) and ExeM (not a Hvo_1477 homolog) in Shewannela species (Godeke et al., 2011a) are known to be involved in DNA metabolism. Deleting yokF and its paralogs (e.g., $y n c B)$ in B. subtilis also greatly reduced but did not abolish growth levels on eDNA (Sakamoto et al., 2001). The use of DNA as a nutrient is considered a form of natural DNA uptake or natural competence (Finkel and Kolter, 2001) (NC); however, in strict terms, NC is defined by internalization of intact DNA fragments and by the presence of a complex 


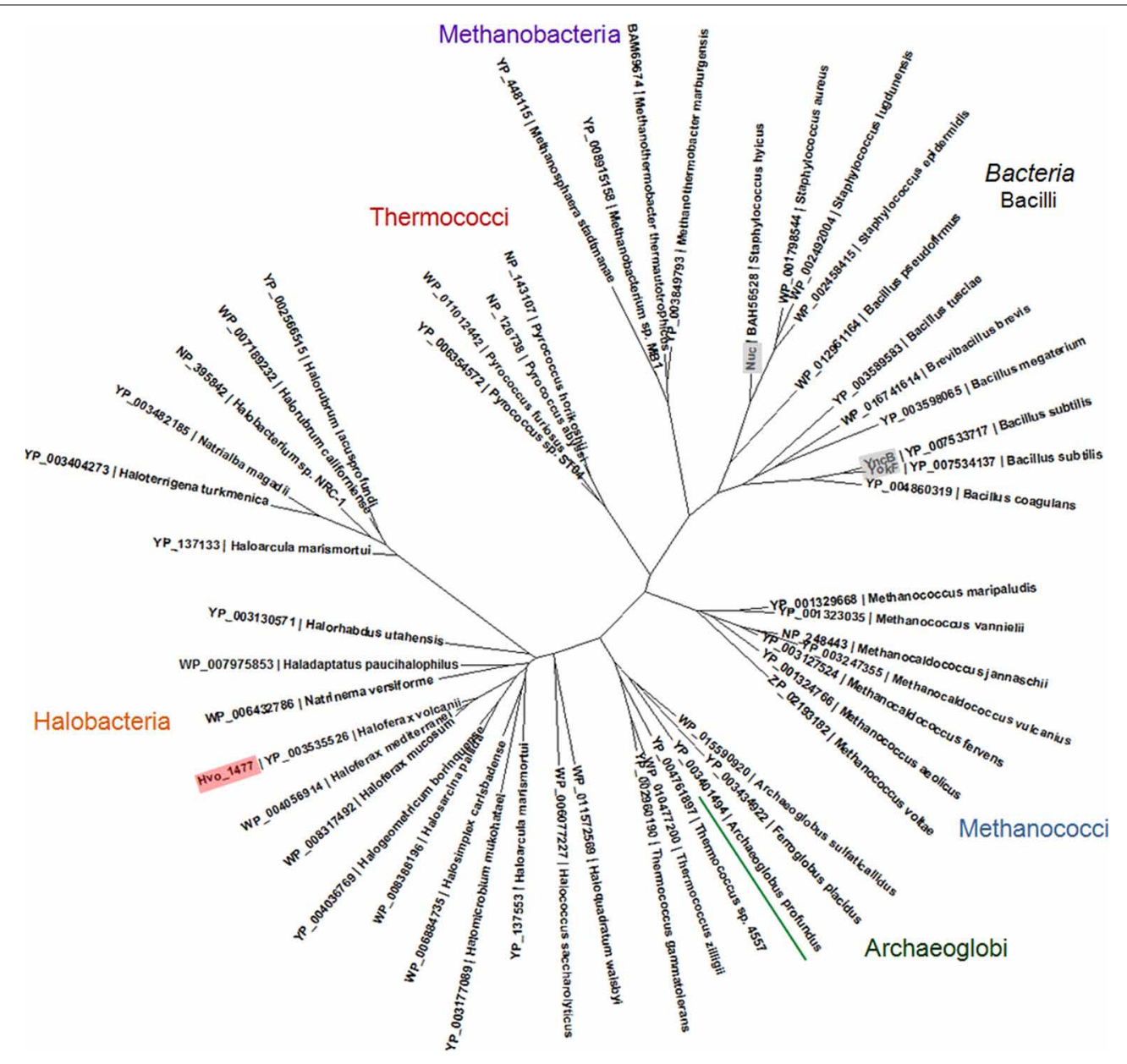

FIGURE 9 | Phylogenetic tree of archaeal YokF/Nuc protein homologs. A protein alignment was created with Clustal Omega (Sievers et al., 2011) and used to create a maximum likelihood tree using PhyML (Guindon and

Gascuel, 2003). Proteins included in alignment were identified in a BLASTP search of the non-redundant protein database and have an $E$-value of $1 \mathrm{e}-10$ or lower in a pairwise BLASTP with YokF. Accession numbers and species names are shown; bacterial proteins with known functions (see also Table 2) are labeled gray. molecular machine responsible for DNA binding, processing, and internalization (Chen and Dubnau, 2004). At this point, we have not conclusively demonstrated that HMW eDNA is imported across halobacterial membranes.

It remains unclear in H. volcanii whether Hvo_1477 is associated with additional surface or transmembrane proteins and if eDNA is imported as HMW DNA into the cell. Other bacterial surface-bound nucleases, including EndA of Streptococcus species and NucA in Bacillus species are responsible for processing eDNA prior to internalization by additional proteins (Provvedi et al., 2001; Chen and Dubnau, 2004). It is possible then that Hvo_1477 also acts as part of an unknown archaeal DNA uptake complex. The observation that $H$. volcanii is biased against most sources of DNA it can utilize for metabolism suggests that HMW DNA is indeed moved across the membrane and into the cell; if DNA hydrolysis occurred extracellularly, and only nucleotides were imported for growth, it is difficult to explain why cells would reject most DNA sources and undergo starvation. Fluorescence microscopy experiments revealed that labeled eDNA co-localizes with $H$. volcanii cells (Figure 5), consistent with the assumption that HMW DNA associates with the cell during a multi-part process of DNA processing and metabolism. Because not all cells co-localized with DNA, it is possible that a fraction of cells within a given population do not express DNA binding factors (i.e., regulated expression) and are unable to associate with eDNA. The identification of protein-protein interactions, regulation, and dynamics of eDNA processing at the cell surface (including cellular binding assays with multiple DNA types), and further biochemical characterization of Hvo_1477 are necessary for further insight.

Drawing from studies of surface-associated nucleases in bacterial species, it seems likely that Hvo_1477 has additional important phenotypes in $H$. volcanii. DNA degradation for "food" is only one useful physiological function of a surface-bound nuclease in the DNA-rich milieu in which prokaryotes live. eDNA has been proposed as a structural element of bacterial biofilm structure (Dominiak et al., 2011; Godeke et al., 2011b), and plays additional roles within a biofilm such as aiding in attachment (Harmsen et al., 2010), selforganization (Gloag et al., 2013), and counteraction of antibiotic 
action (Chiang et al., 2013). It is not surprising then that extracellular nucleases in bacteria (including Hvo_1477 homolog Nuc, Table 2) modulate biofilm development (Kiedrowski et al., 2011). For example, the nucleases Dns in Vibrio cholerae and ExeM in $S$. oneidensis are involved in both eDNA processing for nutrition (ExeM) and/or natural transformation (Dns) and biofilm regulation (Blokesch and Schoolnik, 2008; Godeke et al., 2011a; Seper et al., 2011). Halobacteria form biofilms and like bacterial biofilms, high levels of eDNA are found in archaeal biofilms (Frols et al., 2012). It is possible then that Hvo_1477 is also involved in biofilm lifecycle through its putative activity as a surface-bound nuclease (Table 5).

\section{AUTHOR CONTRIBUTIONS}

Scott Chimileski, Uri Gophna, Kunal Dolas, Adit Naor, and R. Thane Papke conceived of the research and designed the experiments. Scott Chimileski, Kunal Dolas, and Adit Naor carried out and analyzed the experiments, and Scott Chimileski, Uri Gophna, Kunal Dolas, Adit Naor, and R. Thane Papke wrote the manuscript.

\section{ACKNOWLEDGMENTS}

We wish to acknowledge the following agencies for funding this research: National Science Foundation (award numbers, 0919290 and 0830024), the U.S.-Israel Binational Science Foundation (award number 2007043) and NASA Astrobiology: Exobiology and Evolutionary Biology Program Element (Grant Number NNX12AD70G). We thank Dr. Thorsten Allers from the University of Nottingham for the Haloferax strains and plasmids.

\section{REFERENCES}

Allers, T., Barak, S., Liddell, S., Wardell, K., and Mevarech, M. (2010). Improved strains and plasmid vectors for conditional overexpression of His-tagged proteins in Haloferax volcanii. Appl. Environ. Microbiol. 76, 1759-1769. doi: 10.1128/AEM.02670-09

Allers, T., and Mevarech, M. (2005). Archaeal genetics-the third way. Nat. Rev. Genet. 6, 58-73. doi: 10.1038/nrg1504

Allers, T., Ngo, H. P., Mevarech, M., and Lloyd, R. G. (2004). Development of additional selectable markers for the halophilic archaeon Haloferax volcanii based on the leuB and trpA genes. Appl. Environ. Microbiol. 70, 943-953. doi: 10.1128/ AEM.70.2.943-953.2004

Altschul, S. F., Gish, W., Miller, W., Myers, E. W., and Lipman, D. J. (1990). Basic local alignment search tool. J. Mol. Biol. 215, 403-410. doi: 10.1006/jmbi. 1990.9999

Andrei, A. S., Banciu, H. L., and Oren, A. (2012). Living with salt: metabolic and phylogenetic diversity of archaea inhabiting saline ecosystems. FEMS Microbiol. Lett. 330, 1-9. doi: 10.1111/j.1574-6968.2012.02526.x

Atomi, H., Imanaka, T., and Fukui, T. (2012). Overview of the genetic tools in the Archaea. Front. Microbiol. 3:337. doi: 10.3389/fmicb.2012.00337

Averhoff, B. (2009). Shuffling genes around in hot environments: the unique DNA transporter of Thermus thermophilus. FEMS Microbiol. Rev. 33, 611-626. doi: 10.1111/j.1574-6976.2008.00160.x

Benlloch, S., Acinas, S. G., Anton, J., Lopez-Lopez, A., Luz, S. P., and RodriguezValera, F. (2001). Archaeal biodiversity in crystallizer ponds from a solar saltern: culture versus PCR. Microb. Ecol. 41, 12-19. doi: 10.1007/s002480000069

Bitan-Banin, G., Ortenberg, R., and Mevarech, M. (2003). Development of a gene knockout system for the halophilic archaeon Haloferax volcanii by use of the pyrE gene. J. Bacteriol. 185, 772-778. doi: 10.1128/JB.185.3.772-778.2003

Blaby, I. K., Phillips, G., Blaby-Haas, C. E., Gulig, K. S., El Yacoubi, B., and De Crecy-Lagard, V. (2010). Towards a systems approach in the genetic analysis of archaea: accelerating mutant construction and phenotypic analysis in Haloferax volcanii. Archaea 2010:426239. doi: 10.1155/2010/426239
Blokesch, M., and Schoolnik, G. K. (2008). The extracellular nuclease Dns and its role in natural transformation of Vibrio cholerae. J. Bacteriol. 190, 7232-7240. doi: 10.1128/JB.00959-08

Charlebois, R. L., Lam, W. L., Cline, S. W., and Doolittle, W. F. (1987). Characterization of pHV2 from Halobacterium volcanii and its use in demonstrating transformation of an archaebacterium. Proc. Natl. Acad. Sci. U.S.A. 84, 8530-8534. doi: 10.1073/pnas.84.23.8530

Chen, I., Christie, P. J., and Dubnau, D. (2005). The ins and outs of DNA transfer in bacteria. Science 310, 1456-1460. doi: 10.1126/science.1114021

Chen, I., and Dubnau, D. (2004). DNA uptake during bacterial transformation. Nat. Rev. Microbiol. 2, 241-249. doi: 10.1038/nrmicro844

Chesneau, O., and El Solh, N. (1994). Primary structure and biological features of a thermostable nuclease isolated from Staphylococcus hyicus. Gene 145, 41-47. doi: 10.1016/0378-1119(94)90320-4

Chiang, W. C., Nilsson, M., Jensen, P. O., Hoiby, N., Nielsen, T. E., Givskov, M., et al. (2013). Extracellular DNA shields against aminoglycosides in Pseudomonas aeruginosa biofilms. Antimicrob. Agents Chemother. 57, 2352-2361. doi: 10.1128/AAC.00001-13

Corinaldesi, C., Beolchini, F., and Dell'Anno, A. (2008). Damage and degradation rates of extracellular DNA in marine sediments: implications for the preservation of gene sequences. Mol. Ecol. 17, 3939-3951. doi: 10.1111/j.1365-294X. 2008.03880.x

Corinaldesi, C., Dell'Anno, A., and Danovaro, R. (2007). Early diagenesis and trophic role of extracellular DNA in different benthic ecosystems. Limnol. Oceanogr. 52, 1710-1717. doi: 10.4319/lo.2007.52.4.1710

Danovaro, R., Corinaldesi, C., Dell'Anno, A., Fabiano, M., and Corselli, C. (2005). Viruses, prokaryotes and DNA in the sediments of a deep-hypersaline anoxic basin (DHAB) of the Mediterranean Sea. Environ. Microbiol. 7, 586-592. doi: 10.1111/j.1462-2920.2005.00727.x

Dassarma, P., and Dassarma, S. (2008). On the origin of prokaryotic "species": the taxonomy of halophilic Archaea. Saline Syst. 4:5. doi: 10.1186/1746-1448-4-5

Dehal, P. S., Joachimiak, M. P., Price, M. N., Bates, J. T., Baumohl, J. K., Chivian, D., et al. (2010). MicrobesOnline: an integrated portal for comparative and functional genomics. Nucleic Acids Res. 38, D396-D400. doi: 10.1093/nar/gkp919

Dell'Anno, A., and Corinaldesi, C. (2004). Degradation and turnover of extracellular DNA in marine sediments: ecological and methodological considerations. Appl. Environ. Microbiol. 70, 4384-4386. doi: 10.1128/AEM.70.7.43844386.2004

Dell'Anno, A., and Danovaro, R. (2005). Extracellular DNA plays a key role in deepsea ecosystem functioning. Science 309, 2179. doi: 10.1126/science.1117475

Dominiak, D. M., Nielsen, J. L., and Nielsen, P. H. (2011). Extracellular DNA is abundant and important for microcolony strength in mixed microbial biofilms. Environ. Microbiol. 13, 710-721. doi: 10.1111/j.1462-2920.2010.02375.x

Draskovic, I., and Dubnau, D. (2005). Biogenesis of a putative channel protein, ComEC, required for DNA uptake: membrane topology, oligomerization and formation of disulphide bonds. Mol. Microbiol. 55, 881-896. doi: 10.1111/j. 1365-2958.2004.04430.x

Dyall-Smith, M. (2009). Protocols for Haloarchaeal Genetics: The Halohandbook. Ver 7.1. Available online at: http://www.haloarchaea.com/ resources/halohandbook

Facius, D., and Meyer, T. F. (1993). A novel determinant (comA) essential for natural transformation competence in Neisseria gonorrhoeae and the effect of a comA defect on pilin variation. Mol. Microbiol. 10, 699-712. doi: 10.1111/j.1365-2958. 1993.tb00942.x

Finkel, S. E., and Kolter, R. (2001). DNA as a nutrient: novel role for bacterial competence gene homologs. J. Bacteriol. 183, 6288-6293. doi: 10.1128/JB.183.21. 6288-6293.2001

Frols, S., Dyall-Smith, M., and Pfeifer, F. (2012). Biofilm formation by haloarchaea. Environ. Microbiol. 14, 3159-3174. doi: 10.1111/j.1462-2920.2012.02895.x

Gloag, E. S., Turnbull, L., Huang, A., Vallotton, P., Wang, H., Nolan, L. M., et al. (2013). Self-organization of bacterial biofilms is facilitated by extracellular DNA. Proc. Natl. Acad. Sci. U.S.A. 110, 11541-11546. doi: 10.1073/pnas. 1218898110

Godeke, J., Heun, M., Bubendorfer, S., Paul, K., and Thormann, K. M. (2011a). Roles of two Shewanella oneidensis MR-1 extracellular endonucleases. Appl. Environ. Microbiol. 77, 5342-5351. doi: 10.1128/AEM.00643-11

Godeke, J., Paul, K., Lassak, J., and Thormann, K. M. (2011b). Phage-induced lysis enhances biofilm formation in Shewanella oneidensis MR-1. ISME J. 5, 613-626. doi: 10.1038 /ismej.2010.153 
Gough, J., and Chothia, C. (2002). SUPERFAMILY: HMMs representing all proteins of known structure. SCOP sequence searches, alignments and genome assignments. Nucleic Acids Res. 30, 268-272. doi: 10.1093/nar/30.1.268

Gouy, M., Guindon, S., and Gascuel, O. (2010). SeaView version 4: a multiplatform graphical user interface for sequence alignment and phylogenetic tree building. Mol. Biol. Evol. 27, 221-224. doi: 10.1093/molbev/msp259

Guindon, S., and Gascuel, O. (2003). A simple, fast, and accurate algorithm to estimate large phylogenies by maximum likelihood. Syst. Biol. 52, 696-704. doi: 10.1080/10635150390235520

Harmsen, M., Lappann, M., Knochel, S., and Molin, S. (2010). Role of extracellular DNA during biofilm formation by Listeria monocytogenes. Appl. Environ. Microbiol. 76, 2271-2279. doi: 10.1128/AEM.02361-09

Hartman, A. L., Norais, C., Badger, J. H., Delmas, S., Haldenby, S., Madupu, R., et al. (2010). The complete genome sequence of Haloferax volcanii DS2, a model archaeon. PLoS ONE 5:e9605. doi: 10.1371/journal.pone.0009605

Hölzle, A., Fischer, S., Heyer, R., Schutz, S., Zacharias, M., Walther, P., et al. (2008). Maturation of the 5S rRNA $5^{\prime}$ end is catalyzed in vitro by the endonuclease tRNase $\mathrm{Z}$ in the archaeon $H$. volcanii. RNA 14, 928-937. doi: 10.1261/rna.933208

Heins, J. N., Suriano, R., Taniuchi, H., and Anfinsen, C. B. (1967). Characterization of a nuclease produced by Staphylococcus aureus. J. Biol. Chem. 242, 1016-1120.

Kiedrowski, M. R., Kavanaugh, J. S., Malone, C. L., Mootz, J. M., Voyich, J. M., Smeltzer, M. S., et al. (2011). Nuclease modulates biofilm formation in community-associated methicillin-resistant Staphylococcus aureus. PLoS ONE 6:e26714. doi: 10.1371/journal.pone.0026714

Leigh, J. A., Albers, S. V., Atomi, H., and Allers, T. (2011). Model organisms for genetics in the domain Archaea: methanogens, halophiles, Thermococcales and Sulfolobales. FEMS Microbiol. Rev. 35, 577-608. doi: 10.1111/j.1574-6976.2011. 00265.x

Lennon, J. T. (2007). Diversity and metabolism of marine bacteria cultivated on dissolved DNA. Appl. Environ. Microbiol. 73, 2799-2805. doi: 10.1128/AEM. 02674-06

Ludwig, R., Pringault, O., de Wit, R., de Beer, D., and Jonkers, H. M. (2006). Limitation of oxygenic photosynthesis and oxygen consumption by phosphate and organic nitrogen in a hypersaline microbial mat: a microsensor study. FEMS Microbiol. Ecol. 57, 9-17. doi: 10.1111/j.1574-6941.2006.00109.x

Maier, B., Chen, I., Dubnau, D., and Sheetz, M. P. (2004). DNA transport into Bacillus subtilis requires proton motive force to generate large molecular forces. Nat. Struct. Mol. Biol. 11, 643-649. doi: 10.1038/nsmb783

Mulcahy, H., Charron-Mazenod, L., and Lewenza, S. (2010). Pseudomonas aeruginosa produces an extracellular deoxyribonuclease that is required for utilization of DNA as a nutrient source. Environ. Microbiol. 12, 1621-1629. doi: 10.1111/ j.1462-2920.2010.02208.x

Mullakhanbhai, M. F., and Larsen, H. (1975). Halobacterium volcanii spec. nov., a Dead Sea halobacterium with a moderate salt requirement. Arch. Microbiol. 104, 207-214. doi: 10.1007/BF00447326

Oren, A. (1983). Population dynamics of halobacteria in the Dead Sea water column. Limnol. Oceanogr. 28, 1094-1103. doi: 10.4319/lo.1983.28.6.1094

Oren, A., and Shilo, M. (1982). Population dynamics of Dunaliella parva in Dead Sea. Limnol. Oceanogr. 27, 201-211. doi: 10.4319/lo.1982.27.2.0201

Oussenko, I. A., Sanchez, R., and Bechhofer, D. H. (2004). Bacillus subtilis YhcR, a high-molecular-weight, nonspecific endonuclease with a unique domain structure. J. Bacteriol. 186, 5376-5383. doi: 10.1128/JB.186.16.5376-5383.2004

Palchevskiy, V., and Finkel, S. E. (2006). Escherichia coli competence gene homologs are essential for competitive fitness and the use of DNA as a nutrient. J. Bacteriol. 188, 3902-3910. doi: 10.1128/JB.01974-05

Papke, R. T., Douady, C. J., Doolittle, W. F., and Rodriguez-Valera, F. (2003). Diversity of bacteriorhodopsins in different hypersaline waters from a single Spanish saltern. Environ. Microbiol. 5, 1039-1045. doi: 10.1046/j.1462-2920. 2003.00501.x

Papke, R. T., Koenig, J. E., Rodriguez-Valera, F., and Doolittle, W. F. (2004). Frequent recombination in a saltern population of Halorubrum. Science 306, 1928-1929. doi: 10.1126/science.1103289

Pasić, L., Ulrih, N. P., Crnigoj, M., Grabnar, M., and Velikonja, B. H. (2007). Haloarchaeal communities in the crystallizers of two adriatic solar salterns. Can. J. Microbiol. 53, 8-18. doi: 10.1139/w06-091
Pinchuk, G. E., Ammons, C., Culley, D. E., Li, S. M., McLean, J. S., Romine, M. F., et al. (2008). Utilization of DNA as a sole source of phosphorus, carbon, and energy by Shewanella spp.: ecological and physiological implications for dissimilatory metal reduction. Appl. Environ. Microbiol. 74, 1198-1208. doi: 10.1128/ AEM.02026-07

Provvedi, R., Chen, I., and Dubnau, D. (2001). NucA is required for DNA cleavage during transformation of Bacillus subtilis. Mol. Microbiol. 40, 634-644. doi: 10.1046/j.1365-2958.2001.02406.x

Redfield, R. J., Findlay, W. A., Bosse, J., Kroll, J. S., Cameron, A. D., and Nash, J. H. (2006). Evolution of competence and DNA uptake specificity in the Pasteurellaceae. BMC Evol. Biol. 6:82. doi: 10.1186/1471-2148-6-82

Sakamoto, J. J., Sasaki, M., and Tsuchido, T. (2001). Purification and characterization of a Bacillus subtilis 168 nuclease, YokF, involved in chromosomal DNA degradation and cell death caused by thermal shock treatments. J. Biol. Chem. 276, 47046-47051. doi: 10.1074/jbc.M106205200

Schmidt, J. A., Browning, G. F., and Markham, P. F. (2007). Mycoplasma hyopneumoniae mhp379 is a Ca2+-dependent, sugar-nonspecific exonuclease exposed on the cell surface. J. Bacteriol. 189, 3414-3424. doi: 10.1128/JB. 01835-06

Seper, A., Fengler, V. H., Roier, S., Wolinski, H., Kohlwein, S. D., Bishop, A. L., et al. (2011). Extracellular nucleases and extracellular DNA play important roles in Vibrio cholerae biofilm formation. Mol. Microbiol. 82, 1015-1037. doi: 10.1111/ j.1365-2958.2011.07867.x

Sievers, F., Wilm, A., Dineen, D., Gibson, T. J., Karplus, K., Li, W., et al. (2011). Fast, scalable generation of high-quality protein multiple sequence alignments using Clustal Omega. Mol. Syst. Biol. 7, 539. doi: 10.1038/msb.2011.75

Sigrist, C. J., de Castro, E., Cerutti, L., Cuche, B. A., Hulo, N., Bridge, A., et al. (2013). New and continuing developments at PROSITE. Nucleic Acids Res. 41, D344-D347. doi: 10.1093/nar/gks1067

Soppa, J. (2006). From genomes to function: haloarchaea as model organisms. Microbiology 152, 585-590. doi: 10.1099/mic.0.28504-0

Soppa, J. (2013). Evolutionary advantages of polyploidy in halophilic archaea. Biochem. Soc. Trans. 41, 339-343. doi: 10.1042/BST20120315

Steinberger, R. E., and Holden, P. A. (2005). Extracellular DNA in single- and multiple-species unsaturated biofilms. Appl. Environ. Microbiol. 71, 5404-5410. doi: 10.1128/AEM.71.9.5404-5410.2005

Szabo, Z., and Pohlschroder, M. (2012). Diversity and subcellular distribution of archaeal secreted proteins. Front. Microbiol. 3:207. doi: 10.3389/fmicb.2012. 00207

Tatusov, R. L. (1997). A genomic perspective on protein families. Science 278, 631-637. doi: 10.1126/science.278.5338.631

Tehei, M., Franzetti, B., Maurel, M. C., Vergne, J., Hountondji, C., and Zaccai, G. (2002). The search for traces of life: the protective effect of salt on biological macromolecules. Extremophiles 6, 427-430. doi: 10.1007/s00792-002-0275-6

Ventosa, A., Sanchez-Porro, C., Martin, S., Mellado, E., and Gunde-Cimerman, N. (2005). "Halophilic archaea and bacteria as a source of extracellular hydrolytic enzymes," in Adaptation to Life at High Salt Concentrations in Archaea, Bacteria, and Eukarya, eds A. Oren and A. Plemenitas (Dordrecht: Springer).

Conflict of Interest Statement: The authors declare that the research was conducted in the absence of any commercial or financial relationships that could be construed as a potential conflict of interest.

Received: 31 December 2013; paper pending published: 20 January 2014; accepted: 29 January 2014; published online: 20 February 2014.

Citation: Chimileski S, Dolas K, Naor A, Gophna U and Papke RT (2014) Extracellular DNA metabolism in Haloferax volcanii. Front. Microbiol. 5:57. doi: 10.3389/fmicb.2014.00057

This article was submitted to Extreme Microbiology, a section of the journal Frontiers in Microbiology.

Copyright (c) 2014 Chimileski, Dolas, Naor, Gophna and Papke. This is an openaccess article distributed under the terms of the Creative Commons Attribution License (CC BY). The use, distribution or reproduction in other forums is permitted, provided the original author(s) or licensor are credited and that the original publication in this journal is cited, in accordance with accepted academic practice. No use, distribution or reproduction is permitted which does not comply with these terms. 